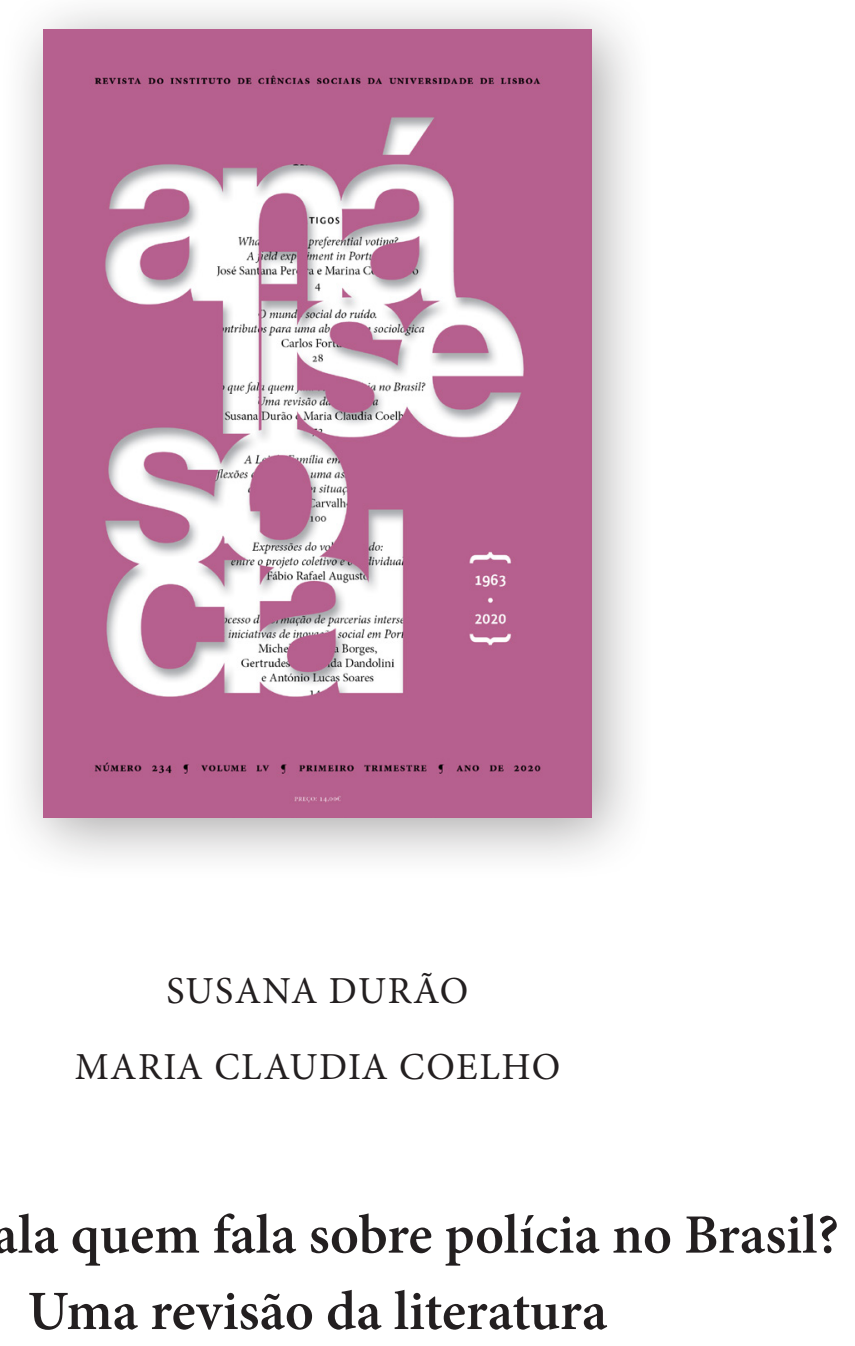

\title{
Do que fala quem fala sobre polícia no Brasil? Uma revisão da literatura
}

\author{
Análise Social, LV (1. $\left.{ }^{\circ}\right), 2020$ (n. $\left.{ }^{\circ} 234\right)$, pp. 72-99 \\ https://doi.org/10.31447/Asoo032573.2020234.03 \\ ISSN ONLINE 2182-2999
}


Análise Social, 234, LV (1. $\left.{ }^{\circ}\right), 2020,72-99$

Do que fala quem fala sobre polícia no Brasil? Uma revisão da literatura. Este artigo pretende mapear literatura selecionada sobre policiamento nas ciências sociais brasileiras nos últimos 20 anos. A primeira parte expõe, com base em textos de revisão bibliográfica, a história da construção do "policiamento" como objeto de pesquisa nas ciências sociais brasileiras. A segunda secção discute a predominância de dois temas (o compromisso da agenda de pesquisa com o tema das violações dos direitos humanos e a convivência tensa entre os modelos do policiamento autoritário/repressivo e comunitário/de proximidade. A terceira parte resenha trabalhos dedicados especificamente às UPP, identificando as suas principais matrizes analíticas. O artigo fornece subsídios para a compreensão do tratamento analítico dado ao policiamento no Brasil para ser lido, comparativamente, com trabalhos académicos de outros países.

PALAVRAS-CHAVE: policiamento; direitos humanos; Unidades de Polícia Pacificadora; segurança pública.

What are they saying about the police in Brazil? A literature review. This article reviews a selected bibliography on policing issues in Brazilian social sciences during the last 20 years. The paper has three parts. The first discusses the history of the construction of "policing" as an object of research in Brazilian social sciences. The second discusses the predominance of two topics: the research agenda's commitment to the issue of Human Rights violations; and the tense coexistence of two policing models (authoritative/repressing and community/ proximity). The third section reviews a set of papers specifically seeking to identify its main analytical axes. The article provides insights of the analytical treatment given to policing in Brazil to be read comparatively in academic scenes of other countries.

KEYWORDs: police; human rights; Pacifying Police Units; public security.

https://doi.org/10.31447/ASO0032573.2020234.03 


\section{Do que fala quem fala sobre polícia no Brasil? Uma revisão da literatura ${ }^{1}$}

\section{INTRODUÇÃO}

O tema do policiamento conta hoje com uma vasta e sólida produção nas ciências sociais brasileiras. Realizamos aqui um inventário analítico das principais tensões que, do nosso ponto de vista, vêm norteando essa bibliografia, com atenção para as perspetivas teóricas usadas para explicar os contornos do policiamento urbano brasileiro. Consideramos que as análises sobre as Unidades de Polícia Pacificadora (UPP), pela atenção académica, social e política recebida, condensam boa parte dos argumentos propostos neste artigo e, por isso, dedicamos uma secção do texto à literatura específica sobre essa iniciativa. Diversos autores antecederam-nos nesta iniciativa de analisar a literatura das ciências sociais brasileiras, mapeando e propondo classificações variadas sobre violência e crime, polícia e ordem pública e políticas públicas de segurança pública (Muniz, Caruso e Freitas, 2018). ${ }^{2}$ Neste artigo, adotámos um procedimento metodológico distinto: a opção seletiva e indutiva por conjuntos de textos específicos, em lugar do esforço de compilação e classificação temática de livros e artigos.

Assim, a nossa argumentação escusa-se à classificação temática, buscando avançar no sentido de encontrar os posicionamentos teórico-analíticos na literatura sobre polícia que selecionámos, convergindo em seguida para a literatura sobre as UPP. Estas são aqui tratadas, como iremos desenvolver, como um

1 Este texto foi elaborado no âmbito do projeto "COPP-LAB: Circulações de Oficiais e Polícia em Portugal, África Lusófona e Brasil”, financiado pela Fundação para a Ciência e Tecnologia em Portugal (2013-2015, PTDC/IVC -ANT/5314/2012), coordenado por Susana Durão.

2 Ver também Zaluar (1999a, 1999b), Lima, Misse e Miranda (2000), Adorno (2001), Barreira e Adorno (2010) e Campos e Alvarez (2017). 
"caso" que ilustra as tensões analíticas mais fortemente expressas na bibliografia sobre os temas que incluem ou tratam a polícia.

O campo de estudos sobre policiamento nas ciências sociais brasileiras apresenta assim uma peculiaridade: a vasta produção não só sobre o objeto que o define, mas também uma "postura reflexiva" constante, com a produção periódica de balanços e revisões bibliográficas. O nosso texto procura acrescentar conhecimento ao esforço que já foi empreendido, acompanhando a leitura de Muniz, Caruso e Freitas (2018), que sublinham na literatura a persistente tentativa em identificar os singulares "problemas das polícias no Brasil", abordagem que determina e enquadra o viés teórico dos estudos sobre policiamento.

Partimos de duas hipóteses preliminares. Por um lado, a existência de um forte compromisso da agenda em pesquisa na área do policiamento com a temática dos direitos humanos, em particular a preocupação com as suas violações. Por outro, a proeminência do tema da coexistência, em regime de tensão, de dois modelos de policiamento: o modelo autoritário-burocrático e o modelo comunitário/de proximidade, tensão esta que atravessaria diversos aspetos do trabalho policial, desde os projetos de formação/treino até às práticas e discursos policiais, abrangendo ainda a opinião pública expressa nos diversos media.

O policiamento, contudo, encontra-se fortemente entrelaçado com outras temáticas ainda mais candentes na agenda de pesquisa das ciências sociais no Brasil. Em particular, destacamos os estudos da violência e da criminalidade, formando uma espécie de "campo" junto com o estudo do policiamento. A associação imediata entre as referidas áreas, por si só, diz muito sobre a visão da polícia no senso comum brasileiro. Essa mesma visão é fortemente impregnante da sua constituição como objeto de estudo pelas ciências sociais, a qual difere da forma como a temática é pensada em outras cenas académicas, e a partir das quais este texto poderá ser lido. Isto é, o grande problema da segurança pública e do policiamento no Brasil é a violência. De modo mais abrangente, o controlo (descontrolo) da violência, ao continuar a ser um dos graves desafios às políticas governamentais (Barreira e Adorno, 2010), atravessa e determina em si mesmo muito do que se escreve sobre polícia.

No decurso da Constituição de 1988, o estudo do policiamento começa a surgir associado ao interesse de promoção de políticas públicas e reforma do Estado no Brasil debaixo da grande categoria "sistema de segurança pública". Em contextos euro-americanos é mais frequente que os estudos policiais gerem noções como policiamentos plurais e nodais (Jones e Newburn, 2006) que remetem para a complexidade de processos, aparatos e atores envolvidos, 
estatais e não estatais. ${ }^{3}$ Nestes contextos, os limites teóricos e empíricos são menos norteados pela agenda pública reformista e mais por tradições de inserção do tema na ampla área da criminologia, estudos legais, ciência e tecnologia e vigilância, estando estas em diálogo com as ciências sociais mas, ao contrário do que sucede no Brasil, escapando ao seu domínio.

Nos principais textos que propõem mapeamentos da bibliografia sobre policiamento no Brasil, em várias épocas, encontramos a tendência de associação direta entre policiamento e violência. Conjuntos de textos recentes tratam as UPP como estudo de caso que ilustra essa tendência e derivações importantes que se resumem na tensão entre a herança e a permanência do que chamamos de modelo policial autoritário-burocrático e as inovações inconclusas ou nefastas de um modelo comunitário/de proximidade.

Este texto propõe assim uma análise de literatura selecionada, e necessariamente limitada, com o objetivo de dar a entender a um público transnacional do que falam os académicos brasileiros quando falam de policiamento. ${ }^{4}$ O trabalho está estruturado em três secções. Na primeira, expomos quatro textos de mapeamento bibliográfico das áreas de estudos sobre violência e criminalidade no Brasil, publicados entre os anos de 1993 e 2013, com o propósito de mostrar esse estreito entrelaçamento temático entre policiamento, violência e criminalidade, enfatizando a forma como o policiamento vai ganhando autonomia enquanto objeto específico da atenção dos cientistas sociais.

$\mathrm{Na}$ segunda secção, inventariamos os principais tópicos abordados pelos autores que se dedicam ao tema do policiamento no universo recortado. Definimos como "campo bibliográfico" principal dois dossiês - Adorno e Peralva (1997) e Muniz e Paes-Machado (2010) -, que trazem análises coletivas norteadoras deste debate, e os primeiros 22 números da revista brasileira Dilemas (especializada nos temas da violência, da criminalidade, do desvio e dos conflitos). Como limite temporal, definimos a publicação de um dossiê sobre as UPP na Dilemas, no início de 2015.

$\mathrm{Na}$ terceira secção, abordamos as matrizes analíticas acionadas para a reflexão sobre as UPP, seja no bojo de políticas públicas para as favelas, seja como política de segurança pública. Destacamos como os textos sobre as UPP

3 Para sermos mais precisas, na literatura anglo-saxónica destaca-se a noção de pluralização dos policiamentos, que recusa circunscrever o policiamento a uma dimensão institucional estatal (Bayley e Shearing, 2001; Scarpello, 2016) e governança nodal da segurança, que evidencia o conjunto de atores políticos e práticos envolvidos na administração dos mercados da proteção (Boutellier e Van Steden, 2011; Johnston e Shearing, 2003; Lebrun e McDonald, 2011; Loader e Walker 2007; Shearing e Wood, 2003; White, 2011; Wood e Dupont, 2006).

4 Para uma leitura complementar ler a coletânea Polícia, Segurança e Ordem Pública. Perspectivas Portuguesas e Brasileiras (Durão e Darck, 2012). 
traduzem precisamente o enfoque tradicional do debate que identificamos na literatura sobre policiamento no Brasil e que pode ser lido com detalhe e precisão em Muniz, Caruso e Freitas (2018).

Nas considerações finais, apontamos alguns desdobramentos possíveis para este esforço de compreensão das linhas mestras que orientam a reflexão sobre policiamento nas ciências sociais brasileiras. A ideia é, ao buscar uma resposta para a inquietação que dá título ao artigo - do que fala quem fala sobre polícia no Brasil? -, realizar um movimento de mão dupla: compreender o percurso da construção desse campo no Brasil e, simultaneamente, oferecer reflexões para futuras análises que comparem os estudos do policiamento com outras tradições e tendências internacionais.

\section{ESTUDOS DO POLICIAMENTO NAS CIÊNCIAS SOCIAIS NO BRASIL: RECORTES E TANGÊNCIAS}

Entre 1993 e 2013, foram realizados alguns esforços de fôlego referentes ao mapeamento bibliográfico da produção das ciências sociais brasileiras sobre os temas da violência e da criminalidade. Nesta secção, expomos, em sequência cronológica, as linhas gerais dessa produção tal como inventariadas pelos autores, procurando evidenciar a existência de uma "malha semântica" na qual surge o objeto "policiamento". O nosso intuito é analisar a maneira como o tema do policiamento se articula, ao longo dessas décadas, com outras temáticas de pesquisa, bem como a sua gradual construção como objeto autónomo.

O primeiro mapeamento ao qual recorremos foi realizado por Sérgio Adorno (1993). O autor principia apontando a ocorrência de uma "guinada disciplinar" nos estudos da criminalidade, os quais estariam deixando de ser exclusividade da abordagem jurídica e começando a merecer a atenção da sociologia.

O foco da revisão está nas "relações entre controle social do crime, violência e poder" (p. 3). O autor classifica tematicamente os estudos encontrados em quatro "categorias": o movimento da criminalidade, a problematização do perfil social dos autores de delitos, a organização social do crime (sob a perspetiva do delinquente) e as análises das políticas públicas penais.

O tema do policiamento surge na última categoria, como parte de uma perceção generalizada de que, para entender a criminalidade, é essencial entender as agências de controlo e repressão. O policiamento, ainda que integre o rol dos "alvos privilegiados de estudo", não aparece ainda como uma rubrica autónoma, compondo o campo da análise das políticas públicas penais juntamente com outras instâncias e atores sociais arrolados por Adorno na mesma 
categoria, tais como o aparelho judiciário, as prisões e as instituições de tutela de jovens infratores.

Paralelamente com essa percepção, insinua-se já um compromisso político e ético: a preocupação com as violações dos direitos humanos, matiz que, conforme defendemos neste artigo, perpassa a literatura mais recente sobre o policiamento. Como diz Adorno:

A não observância, pelos agentes encarregados de manter a ordem pública, dos princípios consagrados na lei destinados à proteção dos direitos civis é freqüentemente invocada, sobretudo pelas organizações de defesa dos direitos humanos, como a responsável pela situação de tensão permanente a que se vê relegado o sistema de justiça criminal. [Adorno, 1993, p. 6]

O segundo mapeamento é publicado seis anos depois por Alba Zaluar, e o seu subtítulo define uma aproximação ao campo semelhante à de Adorno: "violência e crime no Brasil da redemocratização". A autora parte de uma discussão sobre o entrelaçamento entre campo político e campo intelectual, assinalando que as abordagens teóricas eleitas para se analisar a violência e a criminalidade eram tributárias do posicionamento político e da conceção de atuação pública pela qual os cientistas sociais se norteavam. A relação com a agenda dos direitos humanos também é apontada pela autora, produzindo, ao articular-se com a matriz teórica marxista e com o seu compromisso fundamental com a questão da luta de classes, paradoxos de difícil resolução, entre os quais o duplo papel desempenhado pelos "pobres" no enredo da violência, ora como vítimas, ora como agressores.

A escolha da matriz metodológica é um segundo viés importante na maneira como Zaluar traça o quadro da produção intelectual. Os estudos de orientação quantitativa afirmam "a importância dos indicadores sociais ou estatísticas oficiais sobre os crimes na formulação de uma política pública dissuasória" (Zaluar, 1999a, p. 4). E é nos estudos de orientação qualitativa que surge a atenção para com as práticas policiais, lado a lado com "as condições de vida existentes, seja nas áreas onde viviam os candidatos à delinquência, seja nas prisões" (Zaluar, 1999a, p. 4).

Os estudos sobre policiamento são influenciados também pelo posicionamento teórico e político relativo a questões mais abrangentes sobre a sociedade brasileira, em particular o processo de construção da cidadania e de uma ordem democrática. Para Zaluar, já desde os anos 1980 a área de pesquisa sobre violência e criminalidade é marcada por uma clivagem entre a "esquerda penal" (comprometida com a denúncia da miséria e da exploração) e aqueles considerados "de direita", voltados para a análise da "questão institucional, 
inclusive as práticas policiais de violência contra os pobres e a eficiência da polícia em proteger a vida e a propriedade do cidadão, em termos de política pública para todos" (Zaluar, 1999a, p. 4).

$\mathrm{Na}$ análise dos temas predominantes nos textos inventariados pela autora, o "policiamento" já ocupa um lugar de destaque: num universo de 118 trabalhos dedicados às "instituições brasileiras encarregadas de combater o crime e manter a ordem pública" (Zaluar, 1999a, p. 6), a "polícia" é tema de 61 trabalhos. Há, nesse conjunto, etnografias de delegacias policiais e estudos que posicionam a análise da organização da polícia e suas práticas no bojo da rubrica mais ampla da "violência institucional" que marcaria "as mazelas e profundos problemas das políticas públicas brasileiras" (Zaluar, 1999a, p. 8). A "violência policial” surge também, nesse inventário bibliográfico realizado por Zaluar - o qual, é essencial lembrar, tem a "violência" e o "crime" como fios condutores como objeto dotado de autonomia quando se refere à questão mais ampla da "violência advinda do poder ilegítimo do Estado" (Zaluar, 1999a, p. 9).

Um ano depois, Lima, Misse e Miranda (2000) publicam novo mapeamento bibliográfico do tema. Àquelas duas "portas de entrada" que guiam os trabalhos de Adorno e Zaluar, somar-se-iam então os temas da "segurança pública" e da "justiça criminal". Os autores utilizam o Diretório de Grupos do CNPq para mapear o campo, identificando uma forte concentração nas Humanidades, em particular nas Ciências Sociais. O período do levantamento, a exemplo dos textos de Adorno e Zaluar, inicia-se nos anos 1970, e identifica uma forte expansão na década seguinte, com a consolidação da área nos anos 1990.

Lima, Misse e Miranda (2000) delineiam quatro áreas temáticas como eixos para a análise dessa produção: "violência urbana, "delinquência e criminalidade violenta", "polícia e sistema de justiça criminal" e "políticas públicas de segurança”. Embora o policiamento apareça já na segunda rubrica, entrelaçando-se com a questão do crime organizado e do tráfico de drogas, é nas duas últimas áreas temáticas que ganha destaque.

Na rubrica "polícia e sistema de justiça criminal", os autores apontam, a partir dos anos 1980, o desenvolvimento de uma sociologia da organização policial, com ênfase nas formas de entendimento/aplicação das leis. Nos anos 1990, ganham força os estudos das práticas policiais e das violações dos direitos humanos. Já a rubrica das "políticas públicas de segurança" não se constituiria ainda, na visão dos autores, numa área de pesquisa consolidada, estando entrelaçada com uma preocupação "pragmática" do combate à violência. O tema dos direitos humanos aparece aí também, sob a forma da oposição entre repressão e prevenção nas políticas de segurança pública. Nessa rubrica, surgem então alguns temas centrais, como as pesquisas de vitimização voltadas 
para estudar o problema da subnotificação; a discussão em torno da (des) militarização da polícia; o policiamento comunitário; e a relação entre perceções da violência, medo e insegurança.

Finalmente, Nery e Adorno (2013) publicam novo esforço de mapeamento, ainda orientado pelo tema da criminalidade. Realizando um balanço da produção dos anos 1990 e 2000, os autores identificam duas vertentes explicativas principais: aquela que associa a criminalidade às condições económicas e aquela que a explica pelas deficiências no provimento de direitos sociais básicos. Nesse momento, a violação dos direitos humanos por parte do Estado e dos seus agentes torna-se um "importante tema de pesquisa" (Adorno, 2013, p. 11). Data também desse período a importância atribuída ao tratamento matemático das informações e à montagem de grandes bancos de dados para produção de indicadores.

Os autores analisam ainda 300 estudos produzidos entre os anos 1998-2012. Esse período reproduz a clivagem metodológica apontada por Zaluar no seu exame da produção das décadas anteriores, com os trabalhos de orientação qualitativa privilegiando a análise em nível micro das práticas e interações e os estudos de abordagem quantitativa voltando-se para a produção e exame de indicadores sociais. Data também dessa fase o surgimento dos estudos preocupados com as variações intraurbanas que recorrem a análises geoestatísticas.

Tendo situado o lugar do objeto "policiamento" na história dos estudos sobre violência e criminalidade, tal como mapeados nos principais textos recentes de revisão desta literatura, contemplando o período que vai dos anos 1970 a 2012, voltamo-nos agora para um exame dos estudos que utilizam como "porta de entrada" específica a polícia. A polícia e o policiamento tornam-se assim objetos autónomos de estudo, não mais subscritos aos campos mais amplos da violência, crime ou mesmo atores/instituições do sistema de justiça criminal.

\section{A PESQUis a SOBRE POLICIAMENTO E A AGENDA DOS DIREITOS HUMANOS \\ DOSSiÊ “EStratégias DE INTERVENÇão POLICIAL NO ESTADO CONTEMPORÂNEO”}

Este dossiê foi editado a partir de um seminário realizado em 1996, promovido pelo Núcleo de Estudos da Violência da Universidade de São Paulo, e é composto por uma apresentação e treze artigos.

A sua abertura já anuncia a vinculação entre a temática dos direitos humanos e os estudos do policiamento. Falando da preocupação crescente do cidadão comum, em várias partes do mundo, com formas variadas da violência 
(terrorismo, genocídio, perseguições políticas), os autores arrematam assim a sua apresentação do problema: "enfim graves violações do mais elementar dos direitos humanos que é o direito à vida" (Adorno e Peralva, 1997, p. 1).

Os autores prosseguem falando sobre o aumento da preocupação com a criminalidade, percebida não só como intensificada nos seus índices, mas, também, como de natureza crescentemente "violenta". Neste contexto, o Estado é visto como incapaz de zelar pela segurança dos cidadãos, com a emergência do tema da "impunidade".

Surge aí um novo problema: a ambiguidade do trabalho policial. Nas palavras dos autores:

[A] ambiguidade do trabalho policial torna-se manifesta pelas regras que regem suas atividades. Por um lado, exige-se dos policiais elevada produtividade, medida pelo número de prisões efetuadas; por outro lado, pretende-se que eles cumpram essa exigência respeitando rigorosamente os ditames legais. Essa contradição engendra uma cultura organizacional que estimula verdadeira epidemia de práticas ilegais, cujos valores primordiais são o segredo e a solidariedade intra pares. Essas contradições vão igualmente espelhar-se em outras esferas das atividades policiais, como nos processos de seleção e de codificação de casos tratados, muitas vezes com critérios racistas (cf. Wieviorka, 1992) e na própria dificuldade em definir e conceituar o trabalho policial, do ponto de vista de padrões éticos de conduta profissional. [Adorno e Peralva, 1997, p. 2]

Dois temas, fundamentais para este "inventário", entrelaçam-se aqui: (1) - a hipótese de uma contradição entre a "produtividade" do trabalho policial, medida em termos de "número de prisões efetuadas", e a exigência de que isto seja feito em conformidade com os ditames legais; e (2) - os efeitos desta "contradição" sobre uma cultura organizacional que seria perpassada por práticas ilegais.

Os autores finalizam esboçando um comentário sobre a relação existente entre os regimes políticos e o trabalho policial, sugerindo que, onde a tradição democrática é frágil, tenderia a prevalecer o autoritarismo no trabalho policial, colocando-se assim o desafio de como ser eficaz sem recorrer à violência.

Os 13 textos que compõem o dossiê analisam as seguintes temáticas: práticas policiais no contexto das favelas; a relação entre democracia, direitos humanos e práticas policiais; as relações entre polícia e sociedade; o aumento da privatização da segurança na França; outros temas, tais como o estudo do crime organizado, as práticas policiais e a legalidade no exercício da autoridade; o lugar da polícia no sistema judiciário; e uma discussão teórica sobre o conceito de violência. 
DOSSIÊ “POLÍCIA PARA QUEM PRECISA DE POLÍCIA: CONTRIBUiÇões PARA OS ESTUdos SOBRE POLICIAMENTO”

Este dossiê é composto por uma introdução e seis artigos. A exemplo do primeiro dossiê, a introdução também estabelece uma aproximação imediata entre policiamento e violação dos direitos humanos.

$\mathrm{O}$ argumento prossegue esboçando uma distinção entre "polícia" e "policiamento", que seria fundamental para se entender a amplitude dos arranjos criados para a atividade de policiamento. E, a exemplo novamente do percurso realizado na apresentação do primeiro dossiê, envereda por uma discussão sobre a relação entre a polícia e os Estados democráticos e liberais, retomando a problemática da relação entre os direitos humanos e as práticas policiais.

Os autores propõem uma matriz analítica para o estudo das práticas policiais, composta pelo entrelaçamento de três eixos: (a) do ponto de vista da administração ou governo, se é estatal ou não-estatal; (b) do ponto de vista do espaço, se é público ou privado; e (c) do ponto de vista da "referência normativa", se é legal ou ilegal. O entrecruzamento dos três eixos produz oito tipos de práticas policiais que seriam, contudo, apenas possibilidades lógicas, cujo rendimento analítico pretende ser a compreensão não só dos seus "tipos puros”, mas principalmente dos seus hibridismos, a exemplo dos fenómenos citados das "milícias" compostas por agentes do Estado ou da cessão legal de agentes públicos para atividades de policiamento privado em agências bancárias (entre outros).

Os autores finalizam o seu argumento retomando o tema dos direitos humanos, desta feita sob a roupagem da "construção da tolerância":

Ao se tomar o consentimento para policiar em suas dimensões legais e legítimas como uma chave problematizadora, abre-se a possibilidade de uma reflexão mais sensível acerca dos processos de construção da tolerância e dos níveis de aceitação dos indivíduos e grupos policiados em sociedades com Estado. Como resultado, pode-se avançar no entendimento da sutil fronteira entre obediência e sujeição e suas implicações sobre as formas de construção e exercício de autoridade e seus assentimentos. [Muniz e Paes-Machado, 2010, p. 443]

Os textos que compõem o dossiê aprofundam estas temáticas gerais sob prismas particulares: (1) uma experiência de policiamento comunitário realizada em Buenos Aires; (2) a interrelação entre práticas policiais e crenças religiosas; (3) a discricionariedade no exercício da autoridade; (4) a articulação entre violência policial e segurança privada; $(5)$ as práticas policiais em eventos de massa, com ênfase no problema da ordem pública; e (6) a relação 
entre as perceções policiais da eficiência da justiça penal e o desenvolvimento de práticas ilegais de "castigo".

inVENTÁRIO DA TEMÁtiCA DO POLICIAMENTO NA REVISTA Dilemas

Nos primeiros 22 números da Dilemas, há 120 artigos e entrevistas. Entre estes, 23 artigos apresentam, entre as suas palavras-chave, "polícia” (nas suas várias modalidades - civil, militar, federal, etc.) ou segurança pública (com a variação "políticas de segurança”). O exame dos resumos sugere a possibilidade de agruparmos os textos (a despeito de outras aproximações eventuais) em algumas rubricas mais amplas: (1) a relação entre a cultura policial e os valores democráticos, aí incluídas as percepções da cidadania (quatro textos); (2) descrições de políticas de segurança pública (quatro textos); (3) exame (histórico ou descritivo) dos instrumentos da atuação policial (três textos); (4) tipos de policiamento (três textos); (5) ação policial e discriminação (três textos); (6) outros, a saber: polícia federal e crime organizado; policiamento e violência doméstica; ética e práticas policiais; cultura organizacional (quatro textos).

Os dois textos restantes examinam as UPP. É para o exame das chaves analíticas adotadas no seu estudo que nos voltamos agora.

\section{UNIDADES DE POLÍCIA PACIFICADORA: MATRIZES ANALÍTICAS}

AS UPP: UMA POLÍTICA PARA AS FAVELAS

No seu artigo "Novos conflitos na cidade: a UpP e o processo de urbanização na favela", Cunha e Mello partem da assunção de que as UPP integram um "projeto mais amplo de renovação urbana" (Cunha e Mello, 2011, p. 371), cujo objetivo maior seria a preparação do Rio de Janeiro para sediar os megaeventos internacionais da Copa do Mundo de 2014 e das Olimpíadas de 2016. A proposta do texto é analisar, sob uma perspetiva etnográfica, os efeitos das UPP sobre o quotidiano dos moradores da favela Santa Marta (primeira a receber uma UPP em 2008).

Os autores recorrem a uma farta literatura sobre favelas, buscando historicizar a sua emergência no Rio de Janeiro, bem como as suas representações no imaginário da cidade e as principais políticas de Estado a elas dirigidas, entre estas as remoções. Para os nossos propósitos de revisão bibliográfica da literatura sobre policiamento, merece atenção também a perceção da atuação policial nas favelas como abusiva e desrespeitosa em relação aos direitos de cidadania.

O ponto principal dos autores é a visão recorrente das favelas como um espaço urbano marcado pela falta, não só de infra-estrutura como de ordem, em particular no sentido moral do termo, conforme trabalho citado de Jaílson Silva (1997). Neste sentido, a sua análise das UPP considera-as em articulação 
com o projeto das UPP sociais - políticas públicas de construção de infra-estrutura nas áreas "pacificadas".

A análise prossegue examinando o modo como a legalização de diversos serviços - em particular do fornecimento de energia elétrica - tem efeitos sobre a reorganização do espaço urbano da favela, constituindo um passo fundamental na criação de "endereços" na favela, aspetos também evocados por Shirley (1997). Os autores pretendem perceber de que forma esta política de urbanização afeta a visão do mundo local, tendo, portanto, efeitos sobre a identidade dos moradores.

$\mathrm{Na}$ démarche do argumento deste trabalho, as UPP são ponto de partida e de chegada. $\mathrm{O}$ argumento principia apresentando-as como aquilo que permitiria a criação de um ambiente "seguro" para a preparação da cidade para os mega-eventos. Após expor os efeitos dos esforços para criação de infra-estrutura urbana na favela e as perceções dos moradores sobre isto, os autores voltam ao tema das UPP, afirmando:

É certo que a política de segurança pública implementada pelas Unidades de Polícia Pacificadora tem recebido uma avaliação positiva, diminuindo consideravelmente o sentimento de medo e insegurança não só entre os moradores das favelas ocupadas, mas também na população do restante da cidade. Isso já é bastante importante, pois altera significativamente o quadro das relações sociais e políticas no contexto urbano, possibilitando, inclusive, a ressignificação das representações sociais sobre as favelas, esses espaços de habitação popular vistos com tanta desconfiança pela sociedade mais ampla e fortemente estigmatizados. [Cunha e Mello, 2011, p. 395]

Destacamos aqui um primeiro ponto fundamental: diversos leit motifs da literatura sobre policiamento das ciências sociais no Brasil entrelaçam, mais uma vez, em particular as práticas policiais na relação com as camadas populares e o tema da discriminação, que pode derivar em desrespeito pelos Direitos Humanos.

No seu texto "À espera, em ruínas: urbanismo, estética e política no Rio de Janeiro da 'PAcificação", Mariana Cavalcanti (2013) discute os efeitos subjetivos produzidos pelas obras do Programa de Aceleração do Crescimento, do governo federal, sobre as expectativas e a imaginação dos moradores de Manguinhos, no Rio de Janeiro. A autora parte da visão recorrente, nas ciências sociais e no senso comum, de que os problemas das favelas decorreriam da "ausência de Estado". Assim, tal comoCunha e Mello, estabelece uma relação entre a formulação de políticas de segurança pública com o planeamento urbano, no contexto histórico específico de preparação para a Copa do Mundo de 2014 e as Olimpíadas de 2016. 
O trocadilho do título - a "PAcificação" - ilustra bem o ponto da autora: a "crise da segurança pública" precisa de ser pensada em articulação com o "problema da favela". Nas suas palavras: "as obras do PAC constituem apenas um aspeto da sintaxe maior de 'pacificação' das favelas ora em construção" (Cavalcanti, 2013, p. 196).

Nesta discussão, o programa das UPP aparece não como um objeto de análise per se, mas sim como um ingrediente da receita de preparação do Rio de Janeiro para sede daqueles mega-eventos, percepção essa tornada evidente pela distribuição espacial das favelas que vêm merecendo prioridade na instalação das UPP: os locais turísticos e as áreas próximas à realização das competições. Novamente de acordo com a autora:

O que importa aqui é salientar que o acoplamento entre as intervenções em larga escala do PAC e as UPP articula uma gramática de controle social das favelas, que constitui a política de remodelação urbana prevista pelo projeto do Rio como cidade olímpica: é a gramática da PACificação. [Cavalcanti, 2013, p. 197]

As UPP, aqui, compõem o argumento como parte de uma construção do problema cujo cerne parece ser, a exemplo da démarche identificada no texto de Cunha e Mello, o estudo das favelas, em particular do ponto de vista daquilo que os projetos urbanísticos revelam quanto ao seu lugar no imaginário da cidade, tendo como pano de fundo questões ligadas à ordem democrática e à construção da cidadania. O projeto das UPP, assim, é descrito como algo que faz imaginar mudanças, articulado a uma política de urbanização que, até ao momento, não teria produzido, no campo escolhido para análise, mais do que ruínas e abandono.

Nos dois textos revistos, teses sobre o policiamento e teses sobre a favela articulam-se de forma quase inextricável, reforçando a impressão de que falar em polícia, no Brasil, é quase sinónimo de falar em favela, o que acentua ainda mais a perceção da existência de um compromisso da agenda de pesquisa, compromisso esse ao mesmo tempo teórico, ético e político, com a temática das relações entre polícia e camadas populares.

Estes dois textos, publicados com um intervalo de dois anos na mesma revista, escolhem assim uma mesma chave analítica para refletir sobre as UPP. Nela, as UPP servem para pensar as favelas. ${ }^{5}$ Mais do que um programa de

5 Vale dizer que, embora ausentes da análise deste texto, várias outras abordagens sobre policiamento no Brasil urbano, que não apenas restritas aos seus desdobramentos em segmentos de camadas populares, têm tido lugar. Ver, por exemplo, os textos da coletânea de Durão e Darck (2012) e Coelho, Sento-Sé, Silva e Zilli (2013). 
policiamento, são tomadas como uma política pública para as favelas, que se articula com outras políticas públicas (de saúde, de urbanização, artísticas ou desportivas) de superação da clivagem "asfalto/favela”, ao invés de integrar um conjunto complexo de políticas de segurança pública.

\section{AS UPP: UMA AVALIAÇÃO DE IMPACTO DO PROGRAMA COMO POLÍTICA DE SEGURANÇA PÚBLICA}

No seu texto "Cinco anos de Upp: um breve balanço", Daniel Ganem Misse (2014) apresenta como proposta estudar os índices de letalidade associados ao processo de pacificação pretendido pelas UPP. ${ }^{6} \mathrm{O}$ foco do texto é avaliar o seu papel como causa para redução dos índices de criminalidade. Para tanto, o autor cruza os dados relativos às áreas dotadas de UPP com aqueles provenientes do Sistema Integrado de Metas (SIM). Inclui ainda, na parte final, algumas considerações sobre o ethos policial. A preocupação central da análise é o problema da subnotificação, cujas causas podem estar relacionadas, na visão do autor, com três fatores: as próprias UPP, o SIM e o ethos policial.

$\mathrm{O}$ autor principia apresentando uma breve história das UPP. O primeiro tópico abordado são as divergências nas interpretações acerca dos critérios de escolha dos locais de instalação. Em pesquisa realizada pelo Laboratório de Análise da Violência (LAV) da UERJ, a análise sugere, a partir das comunidades escolhidas para instalação das UPP, o traçado de um "cinturão de segurança" desenhado pelos megaeventos desportivos a serem realizados no Rio de Janeiro. Hipótese alternativa é apresentada pelo Instituto de Segurança Pública (ISP) do estado do Rio de Janeiro, que afirma ter sido a escolha norteada pelos índices de criminalidade violenta. Há ainda uma terceira hipótese, aventada por um comandante de uma UPP junto ao autor, e que estaria relacionada com a importância da facção criminosa no controlo da região e sua influência sobre a região metropolitana do Rio de Janeiro. Em seguida, o autor discute o processo de implantação, destacando a participação de "policiais recém-formados com formação em direitos humanos e na doutrina da polícia comunitária” (Ganem Misse, 2014, p. 679), analisando contradições frequentemente detetadas entre violência letal e ações de representação humanitária (Santos, 1997).

6 Nessa linha de avaliação do impacto das UPP na política de segurança pública, Willis e Prado (2014) chamam a atenção para a possibilidade de a UPP, embora não resultante de um processo estrutural de mudança institucional, poder ter viabilidade num processo de reforma menos centralizado. Considerando as UPP uma experiência de "planejamento reflexivo", como designam, proposto a partir da própria realidade brasileira, os autores acreditam no seu potencial transformador, desde que num processo de restauração progressiva da confiança e da conexão entre a população e as forças policiais. 
Em seguida, Ganem Misse prossegue com a análise dos índices de criminalidade nas regiões dotadas de UPP. A sua primeira sugestão é de que “... a UPP se torna uma política de proteção da população contra a própria polícia e o alto grau de letalidade das incursões policiais" (Ganem Misse, 2014, p. 682).

Mas o ponto principal do estudo parece residir no exame das possibilidades de distorção dos índices de registo, no fenómeno conhecido como "sub-notificação". Assim, a presença das UPP parece coincidir com um aumento do número de casos registados, sugerindo assim, à primeira vista, o efeito contrário ao pretendido. Entretanto, a sugestão do autor é que a presença quotidiana dos polícias na comunidade poderia ter levado ao aumento da notificação.

Um segundo ponto na análise do autor sobre as dificuldades em se avaliar as UPP é a introdução do Sistema Integrado de Metas, cujos objetivos são "desencadear ações integradas de prevenção e controlo qualificado do crime e estabelecer as metas para a redução da incidência dos Indicadores Estratégicos de Criminalidade" (2014, p. 687). Essas metas são então tomadas como referência para uma análise de desempenho comparativa, com as regiões e áreas mais bem "classificadas" no ranking de redução dos índices recebendo uma premiação em dinheiro.

Para Ganem Misse, tanto as próprias UPP quanto o sIM poderiam influir nos índices em si, tornando difícil avaliar a sua eficácia. A esse conjunto de considerações sobre eventuais distorções dos índices provocadas pelas mesmas iniciativas que visam reduzi-los, Ganem Misse adiciona algumas reflexões sobre o lugar do ethos policial e seus possíveis efeitos. Seriam dois os traços do ethos policial que poderiam também contribuir para "episódios de truculência e sub-registro de crimes cometidos pelos próprios agentes" (Ganem Misse, 2014, p. 694): as mudanças na representação do policial junto à população (do respeito e temor anteriores à má imagem atual) e a tensão entre os ditames do cumprimento da lei e do respeito ao colega.

O autor levanta ainda a hipótese de que "a redução nos índices de letalidade (poderia) estar a esconder um sub-registo de mortes, ou mesmo a modificação dos registos para desaparecimento para que o policial na ponta cumpra com o sistema de metas proposto" (Ganem Misse, 2014, p. 694). Para explorar essa hipótese, o autor combina quatro tipos de dados: (1) a manutenção de elevados índices de desaparecimento em áreas com upp; (2) o relato de um policial militar; (3) inconsistências nos dados do IsP; (4) e o "caso Amarildo". E conclui o seu argumento comentando as dificuldades da avaliação de impacto das UPP:

Até que ponto o Sistema Integrado de Metas poderia estar colaborando para a subnotificação e mesmo a mudança nos registros de ocorrência? Se, como vimos, o sım estaria 
incutindo um maior controle sobre a ação do policial na ponta, isso poderia estar inibindo diversas práticas de violência e mesmo alterando o seu registro para que sua ação se torne menos visível, da mesma forma que as milícias. [Ganem Misse, 2014, p. 697]

AS UPP: o “POLICIAMENTO COMUnitário" COMO CATEgoria NATIVA

O próximo artigo contemplado nessa exposição é "O que os policiais querem dizer com 'policiamento comunitário': uma análise dos discursos dos oficiais da PMERJ", de Ludmila Ribeiro e Ana Maria Montandon (2014). O seu foco é comparar o significado da noção de "policiamento comunitário" na literatura especializada com os seus sentidos "nativos", explorados a partir de seis entrevistas com os "intelectuais orgânicos" da Polícia Militar do Rio de Janeiro (PMERJ).

A démarche do texto reconstitui as trajetórias dos programas de policiamento comunitário da PMERJ, a partir das quais as autoras examinam as aproximações e afastamentos entre a literatura especializada e as classificações dos oficiais. O ponto central é a forma como posicionam o programa das UPP numa história que inclui diversas outras iniciativas entendidas por eles como do mesmo género.

No Rio de Janeiro, a história do policiamento comunitário começa, segundo os entrevistados, na década de 1980, com a sua implementação nos bairros da Urca, das Laranjeiras e do Grajaú. Há também a criação do Cipoc (Centro Integrado de Policiamento Comunitário), uma experiência que combinava atividades de policiamento com iniciativas nos campos da assistência social, da saúde e da educação. O Cipoc seria, segundo os entrevistados, uma herança da Aciso (Ação Cívico-Social), um projeto do Exército desenvolvido durante o regime militar na área de comunicação. Para os entrevistados, essa associação em alguma medida desafia a possibilidade de "classificação" do Cipoc no rol dos programas de policiamento comunitário, uma vez que lhe faltaria uma perspetiva democrática.

Ainda nos anos 8o, os entrevistados citam o Programa Educacional de Resistência às Drogas (Proerd), que consistia na realização de palestras por polícias nas escolas, visando o combate ao tráfico por meio da prevenção do consumo de drogas. Para as autoras, a inclusão do Proerd pelos entrevistados como um programa de "policiamento comunitário" atestaria a plasticidade do conceito, uma vez que as palestras não seriam "ações de polícia no sentido estrito do termo" (p. 243).

A década de 1990 conhece a primeira experiência de policiamento de quarteirão em Copacabana. Em relação à iniciativa da Urca, os entrevistados apontam, como principais diferenças, um planeamento mais eficaz e a inclusão das fases de monitorização e avaliação. Data dessa década, também, uma expe- 
riência de formação de polícias para a prática do policiamento comunitário: a criação de um batalhão específico (Batalhão Escola de Polícia Comunitária - BPEC) que oferecia aos polícias recém-ingressados na corporação um treino específico para esse tipo de atuação. Essa formação era acoplada a uma passagem por um grupamento especial (Grupamento de Aplicação Prático-Escolar - Gape), que aplicaria esses princípios na "retomada" de territórios "dominados por criminosos". A segunda metade da década (1995-1999) é marcada por um nítido afastamento dos princípios do policiamento comunitário devido à adoção de uma política de segurança pública, em vigor durante o governo de Marcello Alencar, conhecida como "gratificação faroeste", que concedia aumentos salariais aos polícias envolvidos em enfrentamentos que resultavam na morte de bandidos.

No início da década de 2000, há algumas iniciativas que representam a retomada do espírito do policiamento comunitário. Surge o Estágio de Qualificação de Policiamento Comunitário (EQPC), que visava sensibilizá-los para os ideais desse tipo de policiamento. Os objetivos eram reduzir a violência e aumentar o sentimento de segurança. Trata-se, em linhas gerais, de uma reprodução do BEPC. Há também a criação do Grupamento de Policiamento em Áreas Especiais (GPAE), cuja experiência-piloto foi desenvolvida no morro do Pavão-Pavãozinho. Os entrevistados apontam, contudo, a não-priorização do programa, que teria recebido, segundo eles, um "contingente de renegados". O programa foi bem-sucedido do ponto de vista da redução dos índices de homicídios dolosos, sendo considerado pelos media como um "sucesso". Com isso, é expandido para outras áreas e ganha uma coordenação própria que visava garantir uma unidade de ação. O programa, contudo, foi interrompido poucos anos depois, já que não havia um projeto para a continuidade da ação policial uma vez findos os conflitos armados, não havendo integração com a comunidade ou a participação de outras esferas do Estado.

É nesse contexto que, em 2007, surgem as UPP. Para os entrevistados, Gape, GPAE e UPP são uma mesma experiência, com a mudança de nomenclatura devendo-se apenas às mudanças de governo, com cada governador tentando "deixar a sua marca". Essa postura é alvo de muitas críticas por parte dos entrevistados, que a consideram nociva por enganar a população e mesmo os próprios polícias quanto ao ineditismo da experiência, além de dificultar a reconstrução da trajetória institucional do programa.

Para os entrevistados, a principal diferença entre as UPP e os seus antecessores é a criação de uma nova imagem do policial: “... o policial humano, capaz de dialogar com a população, em detrimento do policial que literalmente mata membros da comunidade, como disseminado desde a gratificação faroeste" (Ribeiro e Montandon, 2014, p. 253). Uma segunda diferença seria 
o apoio mediático, que geraria uma maior aceitação das UPP pela população, contrastando-as com a associação do GPAE à corrupção policial. Os entrevistados discutem ainda os requisitos necessários para a perenidade do programa, enfatizando a importância da associação com políticas sociais e da articulação com a comunidade.

\section{AS UPP: O “POLICIAMENTO COMUNitÁRio” COMO CATEgoria NATIVA E CRÍTICA}

Em 2014 e 2015, a Dilemas publica um dossiê com um conjunto de 11 textos integralmente dedicados à análise da implementação de UPP nas favelas cariocas, organizado por Luiz Antonio Machado da Silva e Márcia Pereira Leite. Examinando os textos no seu conjunto, identificamos uma temática dominante e algumas subtemáticas. A ideia dominante nesse dossiê passa pela discussão das UPP como política de manutenção da ordem pública no Rio de Janeiro e que, pela sua exposição e visibilidade, levaria a pôr em questão o lugar das favelas na cidade.

Defendem-se outras análises, referenciadas à primeira ideia: (1) é explorada a análise da noção de "pacificação" contida no programa. Alguns autores defendem que as UPP promovem uma utopia de paz, conivente com metáforas de guerra (através do acionamento no imaginário popular urbano da ideia de favelas como margens disciplinadas integráveis à cidade e, finalmente, a ser "retomadas" pelo Estado)7; (2) é elaborada uma crítica: as UPP resultaram na militarização dos territórios da pobreza e das relações sociais entre polícias e moradores - por intermédio do que é considerado uma ocupação policial e retomada do território. Mas a diferença estaria colocada na ampliação de atuações e mediações dos polícias nas esferas de sociabilidade dos quotidianos das favelas (Teixeira, 2015); (3) as UPP são vistas como dispositivos de gestão moral, alvo de instrumentalidade midiática e potencializadoras de rumores e nuvens de especulação que não as livrariam das permanentes oscilações nas percepções públicas e, consequentemente, do "medo de retorno do medo" (Cunha, 2015, p. 41). ${ }^{8}$

7 Num outro lugar, nesta linha, Pacheco de Oliveira defende que a categoria "pacificação", e o militarismo a ela associado não são novos no Brasil, invocando dinâmicas do mundo colonial. Pacheco propõe aproximações entre o que chama de processos de gestão tutelar de certas comunidades indígenas e de favelas cariocas "pensadas como constituídas não por pessoas e famílias distintas, mas como uma alteridade totalizadora que é em si mesma uma ameaça” (Oliveira, 2014, p. 149).

8 Vale dizer que outros autores dedicaram atenção ao fenómeno das UPP, mas inseriram o mesmo num período maior, mas recente, da história da segurança e policiamento no Rio de Janeiro (entre os anos 1990 e 2000). É o caso de Paul Amar (2013) que identifica no Rio $\rightarrow$ 
Cabe ressaltar, entre as hipóteses interpretativas, aquelas aventadas por Machado da Silva no seu texto "A experiência das Upp: uma tomada de posição" (Silva, 2015), uma vez que o seu argumento oferece o mote crítico aos demais. Silva defende que o projeto e práticas quotidianas em contextos urbanos onde as UPP se instalam oferecem novos contornos para refletir histórica e sociologicamente combinações gramaticais entre o que designa por linguagem dos direitos e linguagem da violência urbana. $\mathrm{O}$ autor sugere que o quadro que autoriza $\mathrm{o}$ surgimento da proposta política das UPP é o de um cansaço coletivo face ao sucessivo endurecimento da política da ordem no Rio de Janeiro desde a década de 90. Assim, a nova política de policiamento, embora situada e específica, significaria o reacender de um debate maior sobre a ordem pública. Apesar das oscilações na sua aprovação social, dos limites e incoerências práticas, misturas de medo e esperança e do avanço e recuo da margem de manobra de empreendedores morais, as UPP implicaram um não retrocesso a um status quo anterior. Todavia, ao verem-se reduzidas a disputas políticas em torno de procedimentos coercitivos - sobretudo após o amplo movimento nacional da "volta às ruas" em 2013 e o apoio social à carga policial sobre os manifestantes - crê o autor que as UPP ficariam irremediavelmente limitadas no seu impacto e abrangência. Silva e vários outros autores do dossiê chamam ainda a atenção para a escassa efetividade do programa que lhe seria complementar, a Upp Social e os seus projetos.

Excetuando esse texto que serve de guia às demais reflexões e dois textos de tom ensaístico (Leite, 2014 e Fridman, 2014), a maioria dos artigos é sustentada por perspetivas de análise interacionista, buscando interpretar o que ocorre entre polícias, moradores e outros agentes envolvidos em diversas favelas onde as UPP operam.

As UpP são assim observadas a partir de vários estudos de caso em favelas e nos media contemplando a sua variação local e também temporal (Rocha e Palermo, 2015; Cunha, 2015). Os temas dos artigos variam entre os desdobramentos do impacto da política UPP na sociabilidade juvenil (Mattos, 2014), venda ambulante (Mesquita, 2014), vida associativa e novos circuitos políticos locais (Silva e Carvalho, 2015), a troca de informações relativa à nova condição territorial entre moradores de favelas ocupadas (Menezes, 2014; Cunha, 2015) e entre os próprios polícias militares (Teixeira, 2015).

$\rightarrow$ a produção do que chama um "estado humano-securitário". Descreve-o não apenas como forma de soberania repressiva, mas como um estado de discórdia e revolta violentamente criativo, repleto de contradições produtivas e oportunidades. Colocando em comparação duas cidades do sul global, Rio de Janeiro e Cairo, Amar dá prioridade à análise de como estas novas formas políticas de segurança dinâmicas - pós-neoliberais, locais e transnacionais, repletas da participação do que chama sujeitos "para-estatais" - formam novos sujeitos de moralidade, género, sexualidade, raça, policiamento e produção do espaço urbano. 
Ainda que remetendo a um intervalo temporal curto, sendo a UPP em Santa Marta o caso mais antigo (com começo em 2008), sobressai em vários textos a tentativa de periodizar os processos locais de instalação, funcionamento e dinâmicas sociais dos últimos anos. A indeterminação (Menezes, 2014) $)^{9}$, questionamentos à sua estrutura e eficácia (Cunha, 2015), as denúncias de desaparecimentos e mortes cada vez mais frequentes (Silva e Carvalho, 2015) - sendo o caso mais mediatizado o homicídio e ocultação por polícias do pedreiro Amarildo de Souza, na Rocinha - fazem temer pelo curso da política das UPP para a ordem pública urbana que, acreditam os pesquisadores, com o correr dos anos acusa o regresso à supremacia da linguagem da violência urbana (Silva, 2015). ${ }^{10}$

\section{CONSIDERAÇÕES FINAIS}

Uma imensa bibliografia sobre polícia e policiamento vem ganhando protagonismo na literatura brasileira sobre violência, criminalidade e justiça penal, a qual, nos últimos anos, se intensifica. Embora com vida curta (nascendo em 2008 e padecendo em 2018) as UPP foram mais do que um programa da Polícia Militar pensado para o Rio de Janeiro e com pretensões expansionistas. As UPP ganharam enorme visibilidade na sociedade carioca, em particular, e na sociedade brasileira, em geral, visibilidade essa que se fez acompanhar de um interesse incomum por parte dos pesquisadores em elegê-las como objeto das suas reflexões.

As UPP aparecem, na revisão que esboçámos, abordadas em três vertentes principais. Primeiro, refletem sobre como estas se converteram numa política para as favelas, em comparação com outras políticas, como a criação ou remoção de infra-estrutura. Segundo, estas são vistas como política de segurança pública, na área das avaliações de impacto. Terceiro, são perspetivadas

9 Várias dissertações e trabalhos de longa duração têm sido dedicados ao polémico tema das UPP no Rio de Janeiro. Para Menezes, que realizou uma pesquisa de campo de quatro anos nas favelas de Santa Marta e Cidade de Deus, as upp significaram uma mudança na fenomenologia do habitar da favela, entre a antiga lógica do "fogo cruzado", baseada no medo constante dos tiroteios, e a lógica do "campo minado", fundada no monitoramento constante e no medo (Menezes, 2015).

10 Vale ressaltar que embora a abordagem destes autores fuja a uma vertente institucionalista, as críticas corroboram análises anteriores que defendem que, mesmo na transição democrática, o sistema policial brasileiro solidificou a sua estrutura descentralizada, a dualidade funcional e a complexa autoridade legal na qual as condições para a corrupção, violência e impunidade são férteis (Caldeira, 2000; Peralva, 2000; Soares, 2006; Zaluar, 2007) ou, num outro sentido, o que foi apelidado como "aspectos neofeudais da Segurança Pública no Brasil" (Reames, 2008). 
como política de manutenção da ordem pública, a partir de abordagens qualitativas que almejam apreender a visão dos polícias e dos habitantes pobres. Essa terceira vertente parece "aplicar" sobre o objeto de pesquisa "UPP" um viés marcante na literatura: aquele que se dedica a examinar a tensão/convivência entre os modelos de policiamento em diversas instâncias, tais como as práticas policiais, os modelos de formação/treinamento e os discursos mediáticos. ${ }^{11}$

$\mathrm{O}$ que pretendemos demonstrar neste texto foi que nas reflexões revistas e analisadas sobre as UPP se atravessam as tensões latentes na literatura mais ampla sobre ou que envolvem o policiamento no Brasil. Duas questões de fundo podem ser identificadas. A literatura brasileira tende a ver a violência e o espírito guerreiro como sendo intrínsecos à cultura policial, sem deixar muitas margens para análises alternativas. Uma outra questão, derivada da primeira, é o facto de a literatura em geral estar mais interessada em mapear o problema da polícia, uma ciência social aplicada à polícia, e menos a polícia e o policiamento em si, a ciência social da polícia (Muniz, Caruso e Freitas, 2018, p. 169, itálicos dos autores). Esta é também uma tendência expressa na literatura sobre as UPP.

Como defendem os referidos autores, quanto mais se caminha para a defesa da grande chave "segurança pública" mais se afigura uma arena de confrontos entre ativistas, operadores, gestores e pesquisadores (Muniz, Caruso e Freitas, 2018, p. 155). Não apenas confrontos, mas consensos. Recentemente veio a público a dissertação de mestrado de Marielle Franco, a vereadora assassinada que é hoje uma das mais conhecidas mártires nacionais e internacionais na luta pelos Direitos Humanos. O título de sua dissertação é muito sugestivo: UPP - A Redução da Favela a Três Letras: uma Análise da Política de Segurança Pública do Estado do Rio de Janeiro (Franco, 2014). Marielle Franco defende, a partir do caso da favela da Maré, que as upP reforçam o modelo de estado penal, repressão e controlo dos pobres, com a consolidação de políticas na área de segurança pública que maquiam e distorcem a realidade. A mesma crítica é reverberada na coletânea intitulada Militarização no Rio de Janeiro: da Pacificação à Intervenção (Farias, Rocha, Leite e Carvalho, 2018) que propõe a análise do legado das UPP no ano do seu término, em 2018. Os capítulos da

11 Várias pesquisas de análise detalhada destes modelos e de suas repercussões praticas têm sido levadas a cabo por equipas de pesquisadores do Centro de Estudos de Segurança e Cidadania (CESec), Núcleo Fluminense de Estudos de Pesquisa (UfF), Laboratório de Estudo da Violência (UERJ), Núcleo de Estudos em Cidadania, Conflito e Violência Urbana (UfRJ), para apenas referir o que vem sendo feito no Rio de Janeiro. Os trabalhos de Michel Misse, Roberto Kant de Lima, João Trajano Sento-Sé, Ignacio Cano e Sílvia Ramos têm sido fundamentais neste campo de estudos desde os anos 90. 
obra podem ser lidos como a confirmação, mais uma vez distópica e radical, da vitória do modelo autoritário-repressivo sobre o comunitário-proximidade nesta experiência. As autoras defendem que, mesmo sendo um programa de policiamento que se pretendia inovador, a UPP termina reforçando e elegendo as piores nuances do policiamento autoritário-militar.

No estilo didático, claro e ao mesmo tempo conceptualmente refinado que é característico de seus textos, Luiz Eduardo Soares (2019) apresenta o corolário da distopia analítica com um pano de fundo, ainda esperançoso, para o campo de estudos da segurança pública, em geral, e do policiamento, em particular, no Brasil. Em Desmilitarizar o autor argumenta que entre os principais problemas na distribuição social e racial da violência estrutural está a arquitetura institucional da segurança pública que tem como ator central a polícia militar e o seu insistente e ambíguo militarismo. A unidade consensual, difícil de almejar entre autores neste campo de estudos vasto e complexo, está menos na proposta de desmilitarização das polícias e do sistema, e mais na definição da violência, seu controlo e descontrolo práticos, como o ponto de partida e de chegada para pensar estes assuntos: "violência não é apenas sintoma, reflexo ou consequência (...) não é necessário nem possível cruzar os braços à espera de que o Brasil se torne menos injusto para, então, cuidar da brutalidade letal, esse dilúvio inominável de tragédias evitáveis" (Soares, 2019, p. 11, itálicos do autor).

A produção hoje solidificada sobre polícia e policiamento no Brasil está muito além do mapeamento aqui realizado e do protagonismo que ganhou o caso das UPP. Entretanto, muito do que é central na discussão sobre a tensão relativa à institucionalização e distribuição (desigual e violenta) da força policial reapresenta-se no debate académico sobre o caso das UPP. O ponto que defendemos aqui é que, nas suas linhas mais gerais, as reflexões sobre as UPP atravessam os problemas levantados pela tradição bibliográfica sobre polícia no Brasil, mesmo se a experiência se cinge ao Estado do Rio de Janeiro. As UPP ocupam um espaço reflexivo que as situa entre o sonho reformista democrático (associado ao modelo de policiamento comunitário) e o pessimismo estrutural sistémico (sistematicamente obstruído por um modelo autoritário -burocrático e militarista que se impõe). Por um lado, os autores escrevem frequentemente numa chave que opera a favor da esperança, sendo a obra de Luiz Eduardo Soares referência-chave desta posição, fundamentada na defesa de um modelo mais comunitário e assistencialista de polícia. Por outro lado, vários autores adotam uma crítica distópica que pretende evidenciar a impossibilidade de com as UPP se ir além do modelo autoritário, violento e militarista das polícias no Rio de Janeiro, como fica expresso no caso da coletânea de Farias, Rocha, Leite e Carvalho (2018). 
Assim, o problema estrutural da violência no Brasil ganha enorme centralidade em toda a reflexão sobre a polícia, e o mesmo acontece quando a reflexão se dirige às UPP. Todavia, e este é o ponto central do nosso texto, a violência é tratada menos como teoria para a polícia e mais como problema da polícia, isto é, como um problema a criticar e a corrigir numa democracia incompleta - o que confere a boa parte da literatura um tom normativo. Assim, não é demais antecipar que análises futuras de experiências sobre o policiamento carregarão a tensão e a disputa incessante que parecem estar enraizadas na própria constituição do campo de estudos sobre policiamento e sobre esse grande calcanhar de Aquiles identificado como sistema de segurança pública brasileiro. Ainda que seguindo diversas abordagens metodológicas, o viés da literatura sobre policiamento no Brasil compromete-se frequentemente com agendas críticas, quando não militantes, das ciências sociais marcadas pela formação de um campo de estudos que visa justificar a imperfeição da passagem destas instituições à ordem democrática.

Não admira assim que a maioria dos artigos inventariados neste texto tenha como referencial a complexa relação entre o policiamento e a violência. Na sua articulação com a centralidade da temática dos Direitos Humanos, poderíamos levantar a hipótese de que o eixo norteador dos estudos sobre o tema nas últimas duas décadas seria: como conceber e construir um lugar para o policial onde sua autoridade para conter a violência se dê dentro de limites legais e amplamente reconhecidos (sendo foco de atenção da generalidade dos autores o frequente deslize entre autoridade e abuso de autoridade)? Ou ainda: como conter a violência (subentendida como função precípua do policiamento) sem fazer dessa contenção uma nova forma de exercício da violência? $\mathrm{O}$ conjunto de textos aqui apresentado demonstra uma tendência crescente que articula o pensamento sobre polícia e as fenomenologias do policiamento violento em favelas. Nesse sentido, a maior parte dos textos evidencia o que ocorre na cidade do Rio de Janeiro como caso paradigmático de policiamento brasileiro, em alguma medida associado a uma violência que persiste e se expande no tempo democrático. Não admira assim que, nos últimos anos, as UPP, enquanto política, programa e experiência de policiamento dirigido e aplicado a territórios pobres de favela tenham tomado, com algumas exceções, toda a cena dos estudos sobre policiamento no Brasil. ${ }^{12}$

12 Em boa medida deve-se ao CEsec o lançamento do debate sobre este tema na opinião pública. No final de 2010, o centro realizou pesquisa nas nove UPP então existentes, ouvindo 359 polícias. Em março de 2012, a pesquisa foi refeita e ouviram-se 775 polícias em 20 UPP. as queixas dos polícias sobre as más condições de trabalho e a relação negativa com a comunidade, podia ler-se que estes não pareciam estar aprendendo a fazer aquilo que supostamente definiria a sua política e conduta: o policiamento de tipo comunitário (Soares, 2012). 
Por um lado, as UpP são alvo de uma crítica académica conduzida por evidências qualitativas e etnográficas que apontam para uma relutante transição em relação ao que estaria na base de práticas violentas do policiamento (podendo estas ser ou não ativadas): um controlo social de estilo militarista sempre sujeito a reconfiguração por debates públicos mais amplos sobre ordens morais na cidade. Assim, para muitos autores, embora apresentado como modelo comunitário de policiamento, as suas dinâmicas manifestam que a novidade do espírito de policiamento comunitário é sistematicamente obstruída por um modelo autoritário-burocrático. ${ }^{13}$

Por outro lado, as UPP são valorizadas na chave da sua análise como contributo positivo e possível política de inversão de um dos maiores dilemas dos direitos humanos nas favelas: o contínuo crescimento do número de homicídios dolosos (que pautou sobretudo os anos 1990). Nesta linha, a reflexão contestaria os limites analisados pela visão anterior, invertendo os termos no seguinte sentido: embora historicamente o policiamento no Brasil, em particular no Rio de Janeiro, se tenha consolidado com base num modelo autoritário-burocrático, a possibilidade de mudança de práticas e de relações sociais, instigada pelas UPP, poderia reabrir, finalmente, a possibilidade para a instalação efetiva de um modelo comunitário de policiamento legítimo. ${ }^{14}$

Quem fala sobre polícia no Brasil fala, assim, sobre muitas coisas que, contudo, se articulam em torno de um eixo central: a relação entre violência e direitos humanos, cuja análise teórica é perpassada por um compromisso ético e político, constituindo-se assim numa agenda de pesquisa que transborda das fronteiras da academia. As UPP, "caso" que privilegiamos aqui para exploração desses veios que atravessam a literatura mais abrangente sobre policiamento, dão margem à reprodução, nas análises de que são objeto, desse problema fundamental, que parece agora estar a ganhar uma nova configuração: o tema da

13 Uma boa síntese desta linha de reflexão pode ser lida num texto muito recente de Jacqueline Muniz (2015). A autora questiona qual seria o ponto certo de uso da força policial, o meio termo entre uma autoridade "nem de mais" (que surgiria das frequentes violações em nome da pacificação) e "nem de menos" (manifesta na ausência prévia das upP em, nos seus termos, "áreas conflagradas" da cidade). Muniz conclui com a incógnita de sempre: como pode o policiamento operar legalmente nas favelas sem ser socialmente legitimado?

14 O Laboratório de Análise da Violência da UERJ publicou, também em 2012, os resultados de uma pesquisa de avaliação do impacto das UPP. Através do recurso combinado a fontes diversas (documentos oficiais, registros criminais e entrevistas semi-estruturadas realizadas com moradores de duas comunidades com UPP e duas comunidades sem UPP), a pesquisa pretendeu mensurar o impacto da nova política sobre a criminalidade, a relação da polícia com a comunidade e a percepção dos moradores em relação à segurança, à participação social, às atividades econômicas e ao estigma incidente sobre as favelas (Cano, Borges e Ribeiro, 2012). 
(des)militarização policial e, também, social, que se vem impondo como novo foco analítico.

\section{REFERÊNCIAS BIBLIOGRÁFICAS}

ADORNO, S. (1993), “A criminalidade urbana violenta no Brasil: um recorte temático”. BIB, 35, pp. 3-24.

ADORNo, S. (2001), "Monopólio estatal da violência na sociedade brasileira contemporânea". In S. Miceli (org.), O que Ler na Ciência Social Brasileira (1970-2002), vol. 4, São Paulo, Anpocs, pp. 167-207.

Adorno, S., PERAlva, A. (1997), "Estratégias de intervenção policial no Estado contemporâneo". Tempo Social, 9(1), pp. 1-4.

amar, P. (2013), The Security Archipelago. Human-Security States, Sexuality Politics, and the End of Neoliberalism, Durham e Londres, Duke University Press.

barreira, C., Adorno, S. (2010), "A violência na sociedade brasileira”. In C. B. Martins, H. H.T.S. Martins (orgs.), Horizontes das Ciências Sociais no Brasil: Sociologia, São Paulo, Anpocs, pp. 303-374.

BAYLEY, D., SHEARING, C. (2001), “The new structure of policing: description, conceptualization, and research agenda”. Research Report, Nova Iorque, National Institute of Justice.

BOUTELlier, H., VAN STEDEN, R. (2011), “Governing nodal governance: the 'anchoring' of local security networks". In A. Crawford, International and Comparative Criminal Justice and Urban Governance: Convergence and Divergence in Global, National and Local Settings, Cambridge, Cambridge University Press, pp. 461-482.

Caldeira, T. (200o), Cidade de Muros. Crime, Segregação e Cidadania em São Paulo, São Paulo, Editora 34 e EDUSP.

Campos, M.S., Alvarez, M.C. (2017), "Políticas públicas de segurança, violência e punição no Brasil (2000-2016)”. In S. Miceli, C. B. Martins, Sociologia Brasileira Hoje, Cotia, Ateliê, pp. 143-217.

CAno, I., Borges, D. e Ribeiro, E. (eds.) (2012), Os Donos do Morro - Uma Avaliação Exploratória do Impacto das Unidades de Polícia Pacificadora (UPP) no Rio de Janeiro, São Paulo, Fórum Brasileiro de Segurança Pública, Rio de Janeiro, LAv/UerJ.

CAVAlCANTI, M. (2013), "À espera, em ruínas: urbanismo, estética e política no Rio de Janeiro da 'PACificação'. Dilemas - Revista de Estudos de Conflito e Controle Social, 6(2), pp. 191-228.

coelho, M.C. et al. (2013), "Autoridade policial, riso e polidez - notas sobre interações entre polícias e cidadãos na operação Lei Seca no Rio de Janeiro". Análise Social, 209, XLVIII $\left(4 .^{\circ}\right)$, pp. 900-920.

CunHA, V. da C. (2015), "O medo do retorno do medo: um ponto de inflexão no programa das upP”. Dilemas- Revista de Estudos de Conflito e Controle Social, 8 (1), pp. 41-62.

Cunha, N. V. da, Mello, M. A. da S. (2011), "Novos conflitos na cidade: a Upp e o processo de urbanização na favela”. Dilemas - Revista de Estudos de Conflito e Controle Social, 4(3), pp. 371-401.

Durão, S., Darck, M. (eds.) (2012), Polícia, Segurança e Ordem Pública. Perspectivas Portuguesas e Brasileiras, Lisboa, Imprensa de Ciências Sociais. 
FRIDMAN, L. C. (2014), "Delegação do poder discricionário: o sonho de paz". Dilemas - Revista de Estudos de Conflito e Controle Social, 7(4), pp. 611-623.

FARIAS, J. et al. (orgs) (2018), Militarização no Rio de Janeiro: da Pacificação à Intervenção, Rio de Janeiro, Editorial Mórula.

Franco, M. (2014), upP: Redução da Favela e Três Letras: uma Análise da Política de Segurança Pública do Estado do Rio de Janeiro. Tese de mestrado, Niterói, Faculdade de Administração, Ciências Contábeis e Turismo, Universidade Federal Fluminense.

Ganem misse, D. (2014), "Cinco anos de upp: um breve balanço". Dilemas - Revista de Estudos de Conflito e Controle Social, 7(3), pp. 675-700.

Johnston, L., Shearing, C. (2003), Governing Security: Explorations in Policing and Justice, Londres, Routledge.

Jones, T., newburn, T. (eds.) (2006), Plural Policing. A Comparative Perspective, Nova Iorque, Routledge.

KANT DE lima, R., Misse, M. e Miranda, A.P. (2000), "Violência, criminalidade, segurança pública e justiça criminal no Brasil: uma bibliografia”. Revista Brasileira de Informação Bibliográfica em Ciências Sociais, São Paulo, 50, pp. 45-123.

Lebrun, E., mcdonald, G. (coord.). Small Arms Survey 2011: States of Security, Cambridge, Cambridge University Press.

LEITE, M.P. (2014), “Entre a 'guerra' e a 'paz': unidades de polícia pacificadora e gestão do territórios de favela no Rio de Janeiro". Dilemas - Revista de Estudos de Conflito e Controle Social, 7(4), pp. 625-642.

LIMA, R.K., Misse, M. e miranda, A.P.M. de (2000), "Violência, criminalidade, segurança pública e justiça criminal no Brasil: uma bibliografia”. ВIB, 50, pp. 45-123.

LOAder, I., WAlker, N. (2007), Civilizing Security, Cambridge, Cambridge University Press.

matTos, C. dos S. (2014), “Parado na esquina’: performances masculinas e identificações entre 'bondes' juvenis na Nova Holanda, Maré, RJ”. Dilemas - Revista de Estudos de Conflito e Controle Social, 7(4), pp. 643-663.

MESquita, W.A.B. (2014), "Quando o trabalho é desordem: as demandas dos vendedores ambulantes com a chegada da UPP ao complexo do alemão". Dilemas - Revista de estudos de conflito e controle social, 7(4), pp. 685-702.

MENEZES, P. V. (2014), “Os rumores da 'pacificação': a chegada da UPP e as mudanças nos problemas públicos no Santa Marta e na Cidade de Deus”. Dilemas - Revista de Estudos de Conflito e Controle Social, 7(4), pp. 665-684.

menezes, P. V. (2015), Entre o "Fogo Cruzado" e o "Campo Minado": Uma Etnografia do Processo de 'Pacificação' de Favelas Cariocas. Tese de doutoramento, Rio de Janeiro, Universidade do Estado do Rio de Janeiro.

Muniz, J. de O. et al. (1997), "Resistências e dificuldades de um Programa de Policiamento Comunitário”. Tempo Social, 9(1), pp. 197-213.

muniz, J. de O., PAES-MAChado, E. (2010), "Polícia para quem precisa de polícia”. Caderno CRH, 6o, pp. 437-447.

MUNIZ, J. de O., siLva, W.F. da (2010), "Mandato policial na prática: tomando decisões nas ruas de João Pessoa”. Caderno CRH, 6o, pp. 449-473.

MUNiz, J. de O., MELlo, K.S.S. (2015), "Nem tão perto, nem tão longe: o dilema da construção da autoridade policial nas UPP”. Civitas, 15(1), pp. 44-65.

MUNIZ, J., CARUSO, H., FreITAS, F. (2018), “Os estudos policiais nas ciências sociais: um balanço sobre a produção brasileira a partir dos anos 2000”. вIB, São Paulo, 84(2), pp. 148-187. 
OLIVEIRA, J.P. de (2014), "Pacificação e tutela militar na gestão de populações e territórios". Mana, 20(1), pp. 125-161.

NERY, M.B., ADORno, S. (2013), "O movimento da criminalidade em São Paulo: um recorte temático e bibliográfico”. BIB, 76, pp. 5-32.

Peralva, A. (200o), Violência e Democracia: O Paradoxo Brasileiro, Rio de Janeiro, Paz e Terra. PINHEIro, P.S. (1997), "Violência, crime e sistemas policiais em países de novas democracias". Tempo Social, 9(1), pp. 43-52.

REAmes, B. N. (2008), "Neofeudal aspects of Brazil's public security". In M. R. Haberfeld e I. Cerrath (eds.), Comparative Policing, Londres, SAgE Publications, pp. 61-95.

Ribeiro, L., montandon, A.M. (2014), "O que os policiais querem dizer com 'policiamento comunitário’: uma análise dos discursos dos oficiais da PMERJ”. Dilemas - Revista de Estudos de Conflito e Controle Social, 7(2), pp. 233-260.

RIOS, A.L. (2010), "Gubernamentalidad y poder de policía: la articulación de um modelo de policiamento dual em Buenos Aires, 2004-2007". Caderno CRH, 60, pp. 487-510.

ROCHA, L. de M., PALERMo, L.C. (2015), “'O morro está na calmaria’: mídia impressa e o repertório da paz no contexto da pacificação”. Dilemas - Revista de Estudos de Conflito e Controle Social, 8(1), pp. 25-40.

SANTos, J.V.T. dos (1997), "A arma e a flor: formação da organização policial, consenso e violência". Tempo Social, 9(1), pp. 155-167.

SCARPELLO, F. (2016), "Toward the political economy of plural policing: taking stock of a burgeoning literature". International Studies Review, 19(3), pp. 407-429.

SHEARING, C., WOOD, J. (2003), "Nodal governance, democracy, and the new 'denizens'”. Journal of Law and Society, 30(3), pp. 400-419.

SHIRLEY, R. (1997), "Atitudes com relação à polícia em uma favela no sul do Brasil". Tempo Social, 9(1), pp. 215-231.

SILVA, J. da (1997), "Representação e ação dos operadores do sistema penal no Rio de Janeiro". Tempo Social, 9(1), pp. 95-114.

SIlva, L. A. M. da (2015), "A experiência das upP: uma tomada de posição". Dilemas - Revista de Estudos de Conflito e Controle Social, 8(1), pp. 7-24.

silva, M.C. de A., CARvalho, M.B. (2015), "Circuitos políticos em uma favela pacificada: os desafios da mediação". Dilemas - Revista de Estudos de Conflito e Controle Social, 8(1), pp. 63-76.

SOARES, B. M. (ed.) (2012), "Unidades de polícia pacificadora: o que pensam os policiais - Ano II". CEsec. Centro de Estudos de Segurança e Cidadania. Disponível em http://www.ucamcesec.com.br/wordpress/wp-content/uploads/2011/o9/Relatorio2012comAnexos.pdf.

SOARES, L.E. (2006), Segurança tem Saída, Rio de Janeiro, Editora Sextante.

soares, L.E. (2019), Desmilitarizar. Segurança Pública e Direitos Humanos, São Paulo, Boitempo.

TEIXeIRA, C. P. (2015), “O 'policial social': algumas observações sobre o engajamento de policiais militares em projetos sociais no contexto de favelas ocupadas por UPP". Dilemas Revista de Estudos de Conflito e Controle Social, 8(1), pp. 77-96.

white, A. (2011), "The new political economy of private security". Theoretical Criminology, 16(1), pp. 85-101.

Wieviorka, M. (1992), “O novo paradigma da violência”. Tempo Social, 9(1), pp. 5-41. wood, J., Dupont, B. (2006), Democracy, Society and the Governance of Security, Cambridge, Cambridge University Press. 
ZALuAR, A. (1999a), "Um debate disperso: violência e crime no Brasil da redemocratização”. São Paulo em Perspectiva, São Paulo, 13(3), pp. 3-17.

Zaluar, A. (1999b), "Violência e crime". In S. Miceli (org.). O que Ler na Ciência Social Brasileira (1970-1995), v. 1, São Paulo, Sumaré; Anpocs, pp. 13-107.

ZALUAR, A. (2007), "Democratização inacabada: fracasso da segurança pública”. Estudos Avançados, 21(61), pp. 31-49.

Recebido a 27-09-2018. Aceite para publicação a 19-08-2019.

DURÃo, S., COELHO, M. C. (2020), "Do que fala quem fala sobre polícia no Brasil? Uma revisão da literatura". Análise Social, 234, LV (1. $\left.{ }^{\circ}\right)$, pp. 72-99.

Susana Durão »sdurao@unicamp.br »Departamento de Antropologia, Instituto de Filosofia e Ciências Humanas (IFCH), Unicamp » Rua Cora Coralina, 100 - CEP 13083-896 Cidade Universitária, Campinas, SP - Brasil » https://orcid.org/oooo-0oo1-8096-6806.

Maria Claudia Coelho » mccoelho@bighost.com.br » Instituto de Ciências Sociais, Universidade do Estado do Rio de Janeiro (ICS/UERJ) » Rua São Francisco Xavier, 524, sala 2015 F — CEP 20550-013, Maracanã, Rio de Janeiro, RJ - Brasil » https://orcid.org/oooo-0003-3885-5429. 